\title{
Distributional and seasonal patterns of ctenophores in Malangen, northern Norway
}

\author{
Tone Falkenhaug* \\ Norwegian College of Fishery Science, University of Tromsø, N-9037 Tromsø, Norway
}

\begin{abstract}
Annual cycles of abundance of the ctenophore species Bolinopsis infundibulum and Beroe cucumis were studied in the Malangen fjord, northern Norway, during 1992. The seasonal dynamics were characterized by alternating abundances of the 2 species. A biomass increase of $B$. infuncibulum occurred in April and May, reaching a peak of 2 to $7 \mathrm{ml} \mathrm{m}^{-3}$ wet volume in the surface layers in summer. The species started to reproduce in the inner part of the fjord, and then propagated throughout the entire fjord system. Length frequency distributions indicated that $B$. infundibulum were reproducing continuously during the summer months. Biovolumes of B. infundibulum decreased in August, leaving a small number of individuals $\left(<1 \mathrm{lnd}\right.$. per $\left.5700 \mathrm{~m}^{3}\right)$ to overwinter in the water column. Small individuals of $B$. cucums occurred in the surface layers in spring. Bıovolumes of this specles were low during summer, but increased in the fall, and a large overwintering population $\left(2\right.$ to $\left.6 \mathrm{ml} \mathrm{m}^{-3}\right)$ was present in the deep basins of the fjord (below $200 \mathrm{~m}$ ) from September to April. The calculated predatory impact of $B$. cucumis on $B$. infundibulum increased during summer (from 6 to $50 \%$ ), and contributed to the autumn decrease in volume of $B$. Infundibulum. The winter population of $B$. cucumis would be short of food if ctenophores were the only prey. Possible mechanisms contributing to the observed patterns are discussed
\end{abstract}

KEY WORDS: Ctenophora Seasonality Zooplankton Predation Fjord Northern Norway

\section{INTRODUCTION}

Ctenophores have been observed to occur in strongly seasonal pulses in many locations (Nelson 1925, Greve 1970, Baker 1973, Hirota 1974, Larson 1986). High feeding and growth rates combined with high fecundity enable ctenophores to react quickly to changes in the environment, and the annual biomass extremes often span several orders of magnitude Ctenophores are considered to be important regulators of mesozooplankton in coastal marine waters (Kremer 1979. Greve \& Reiners 1980, 1988). However, in spite of many reports on mass occurrences of ctenophores in northeastern Atlantic waters during summer, the amount of quantitative data on the vertical distribution and seasonal abundance is limited and little is known about the fate of ctenophore populations during the

\footnotetext{
•E-mail: tonef@nfh.uit.no
}

winter (Mountford 1980). In order to understand the role of ctenophores in the pelagic food web, more quantitative information is needed on population dynamics and seasonal distributions.

The lobate ctenophore Bolinopsis infundibulum is a common macroplanktonic organism of northern and Arctic seas (Bigelow 1926, Zelickman 1972, Lenz 1973). Because this species is an extremely delicate planktonic animal, information regarding its biology and distribution is scarce. Like other lobates, the feeding rate of $B$. infundibulum is high (Gamble 1974 1977), and closely related lobates are known to control their prey populations (Reeve \& Walter 1978). Species of the genus Beroe feed primarily on other ctenophores (Swanberg 1974, Harbison et al. 1978) and may significantly affect the population structure of $B$. infundibulum, and thus indirectly modify the population dynamics of other zooplankton at lower trophic levels (Kamishlov et al. 1958, Kamishlov 1960). The interaction between Beroe cucumis and its ctenophore prey 


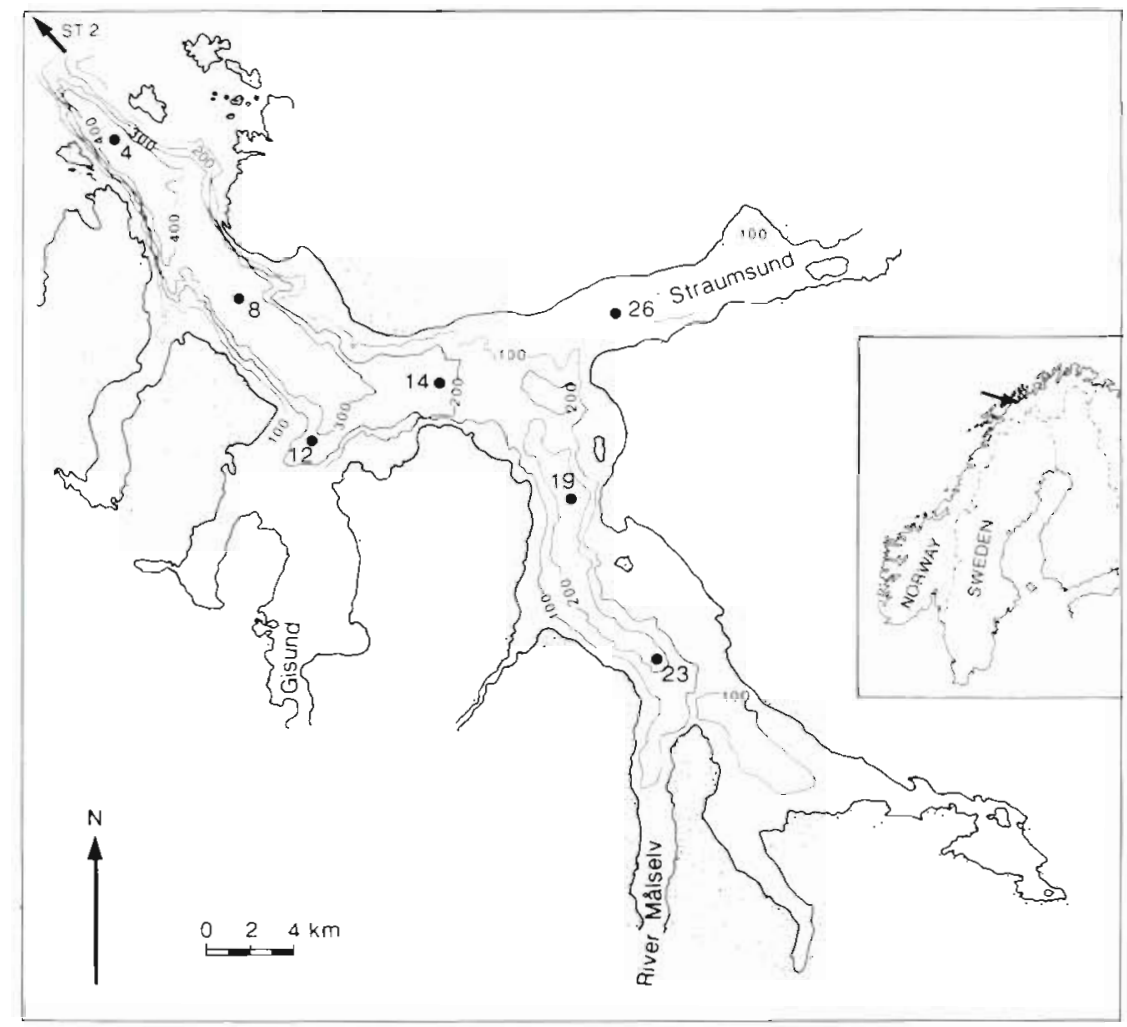

Fig. 1 The Malangen fjord system with sampling stations. Stn 2 is situated $15 \mathrm{~km} \mathrm{NW}$ of Stn 4 (indicated by arrow) was described as an 'ecological feedback system' by Greve (1971, 1981)

The ecology of ctenophores in northern Norwegian waters has not been investigated previously, and the distribution of ctenophores is largely unknown within this region. However, Bolinopsis infundibulum and Beroe cucumis have been observed to occur in high abundances in coastal waters off northern Norway during summer. The purpose of the present study was to obtain quantitative information on the seasonal abundance and spatial distribution of ctenophores in a boreal marine ecosystem, and investigate the interaction between 3 trophic levels. Here I present seasonal, horizontal and vertical variations in occurrences of mesozooplankton, B. infundibulum and B. cucumis during 1992 in a North Norwegian fjord system, and suggest possible mechanisms contributing to the observed patterns.

\section{MATERIALS AND METHODS}

Malangen (Fig. 1) is located $30 \mathrm{~km}$ to the south of Tromsø, in northern Norway $\left(69^{\circ} 30^{\prime} \mathrm{N}, 18^{\circ} 21^{\prime} \mathrm{E}\right)$. The fjord is $50 \mathrm{~km}$ long with an average width of $5 \mathrm{~km}$ and a maximum depth of $400 \mathrm{~m}$. It is separated from the ocean to the northwest by a $200 \mathrm{~m}$ deep sill and is connected to adjacent fjords through 2 narrow sounds with shallow sills (10 and $30 \mathrm{~m}$ ). A more detailed description of the fjord is given in Falkenhaug et al. (1995).

Data on ctenophores, zooplankton and hydrography were collected once a month from February to December in 1992. Stations (Fig. 1) were situated along an axis extending from waters outside the fjord mouth to the fjord head (Stns 2 to 23). Two more stations were situated in the outlets of adjacent fjords (Stns 12 and 26). Temperature and salinity were measured at each station with a Neil Brown CTD profiler. Methods and results with respect to physical oceanography in the fjord are presented in Falkenhaug et al. (1995) Samples of ctenophores and other zooplankton were obtained from 5 to 7 depth strata at each station by a $1 \mathrm{~m}^{2}$ MOCNESS with $180 \mu \mathrm{m}$ mesh size nets (Wiebe et al. 1985) towed at 1 knot (Table 1). The duration of each tow was 30 to 40 min and volume of water filtered was 560 to $12.50 \mathrm{~m}^{3}$ per tow. Stns 8 and 19 were sampled by both day (10:00 to 14:00 h local time) and night (22:00 to $02: 00 \mathrm{~h}$ local time) in order to detect changes in the vertical distributions of ctenophores and mesozooplankton.

Ctenophores were immediately removed from the samples, and placed in a $1000 \mu \mathrm{m}$ sieve for the removal of excess water. The total wet volume of both species in the sample was assessed when the animals had been poured into a measuring cylinder. Torn specimens and 
Table 1 Intervals of MOCNESS samplung in Malangen 1992

\begin{tabular}{|c|c|c|c|c|c|c|c|c|}
\hline \multirow{2}{*}{$\begin{array}{l}\text { Depth strata } \\
\text { (m) }\end{array}$} & \multirow[b]{2}{*}{2} & \multirow[b]{2}{*}{4} & \multirow[b]{2}{*}{8} & \multicolumn{2}{|c|}{ Stations } & \multirow[b]{2}{*}{19} & \multirow[b]{2}{*}{23} & \multirow[b]{2}{*}{26} \\
\hline & & & & 12 & 14 & & & \\
\hline $0-20$ & $x$ & $x$ & $x$ & $x$ & $x$ & $x$ & $x$ & $x$ \\
\hline $20-50$ & $x$ & $x$ & $x$ & $x$ & $x$ & $x$ & $x$ & $x$ \\
\hline $50-100$ & $x$ & $x$ & $x$ & $x$ & $x$ & $x$ & $x$ & $x$ \\
\hline $100-150$ & $x$ & $x$ & $x$ & $x$ & $x$ & $x$ & $x$ & \\
\hline $150-200$ & $x$ & $x$ & $x$ & $x$ & $x$ & $x$ & $x$ & \\
\hline $200-250$ & $x$ & $x$ & $x$ & $x$ & $x$ & $x$ & & \\
\hline 250 -bottom & $x$ & $x$ & $x$ & & & & & \\
\hline
\end{tabular}

fragments of ctenophore body tissue were also included in these volume measurements. Following the removal of all ctenophores from the sample, the remaining zooplankton sample was split with a Motoda splitter device (Motoda 1959). One half of the sample was frozen in liquid nitrogen for determinations of ash free dry weight (AFDW) and the other was preserved in $4 \%$ formalin solution for later species identification and enumeration. In this paper, I have only presented the biomass data. Frozen samples were thawed in filtered seawater at room temperature and shrimps, fish larvae, euphausiids and chaetognaths were sorted out (data not presented here). The remaining zooplankton (mainly copepods) were dried to constant weight at $60^{\circ} \mathrm{C}$ and ashed at $500^{\circ} \mathrm{C}$ to obtain dry weight and AFDW.

For a more careful sampling of ctenophores, vertical hauls with a WP3-net $(1 \mathrm{~m}$ opening diameter, $1000 \mu \mathrm{m}$ mesh size; UNESCO 1968) fitted with a large cod-end (20 l) were made at each station. The nets were hauled at a speed of $0.5 \mathrm{~m} \mathrm{~s}^{-1}$ in 2 or 3 depth strata with the use of a closing mechanism. Body lengths and the wet volume of undamaged ctenophores in the net were measured immediately after collection. Body sizes, defined as gut length of Bolinopsis infundibulum and total body length of Beroe cucumis, were measured to the nearest $\mathrm{mm}$ with a $1 \mathrm{~mm}$ grid under a petri dish. Gut contents (as present or non-present) of undamaged individuals were noted immediately after collection. Due to cod-end feeding and losses of gut content when disturbed (pers. obs.), the gut content analyses were only used as indications of seasonal variations in the feeding activity.

\section{RESULTS}

\section{Hydrography}

The seasonal variation of hydrographic conditions at Stn 8 illustrates the influence of the coastal waters on this fjord (Fig. 2). Salinities were always high in the
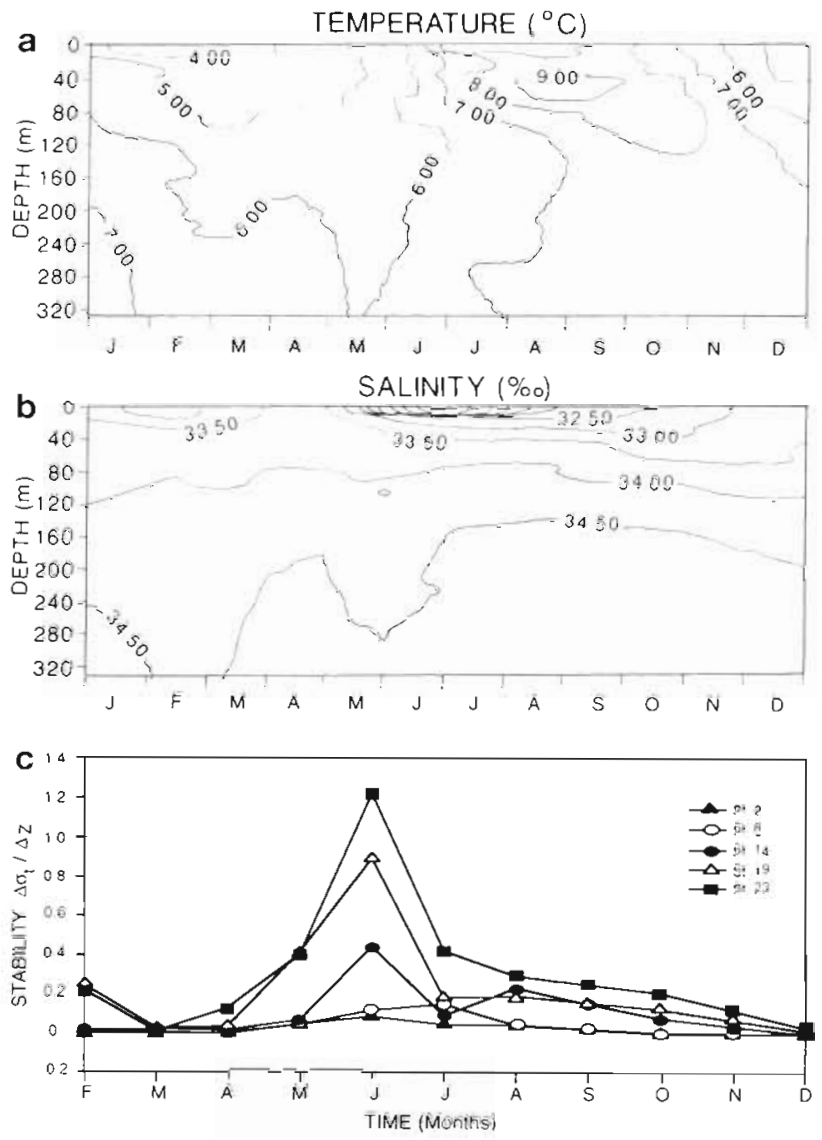

Fig. 2. Seasonal variation in (a) temperature $\left({ }^{\circ} \mathrm{C}\right)$ and (b) salinity $[\%]$ at Stn 8 in 1992 . (c) Stability in the upper $20 \mathrm{~m}$ at different stations in Malangen in 1992

deeper layers, and temperatures increased towards the bottom, with a small annual range $\left(5\right.$ to $\left.7^{\circ} \mathrm{C}\right)$ below $120 \mathrm{~m}$. Heating of the surface layer occurred during the summer months, but temperatures never exceeded $10^{\circ} \mathrm{C}$. A halocline at a depth of $10 \mathrm{~m}$ occurred during summer (May to August) due to freshwater run-off from the river Målselv at the fjord head. The stratification started earlier, disappeared later, and was more pronounced in the inner part of the fjord system (Fig. 2c).

\section{Non-gelatinous zooplankton}

Biomasses of mesozooplankton were low at all stations during the winter, increased during the summer season and reached maximum values $(25$ to $30 \mathrm{~g}$ AFDW $\mathrm{m}^{-2}$ ) in late summer and fall (Table 2). No differences in vertical distribution of mesozooplankton biomass between day and night could be detected at Stns 8 and 19 (data not shown). However, the vertical distributions of the biomass varied with season. High 
Table 2. Mesozooplankton biomass ( $\mathrm{g}$ AFDW $\mathrm{m}^{-2}$ ) in Malangen from February to December 1992. The proporton of biomass (\%) located above $50 \mathrm{~m}$ at each station is given in parentheses

\begin{tabular}{|c|c|c|c|c|c|c|}
\hline \multirow[t]{2}{*}{ Month } & \multicolumn{6}{|c|}{ Station } \\
\hline & 2 & 4 & 8 & 14 & 19 & 23 \\
\hline Feb & $0.02(0.0)$ & $0.04(0.0)$ & $2.6(15.1)$ & $0.9(13.4)$ & $3.4(14.3)$ & $=$ \\
\hline Mar & $0.4(9.9)$ & $0.8(10.7)$ & $0.7(18.2)$ & $0.05(29.8)$ & $0.4(20.0)$ & $0.4(42.7)$ \\
\hline Apr & $1.5(26.0)$ & $1.5(42.6)$ & $0.9(32.4)$ & $1.4(51.3)$ & $0.8(64.0)$ & $1.4(64.0)$ \\
\hline May & - & - & $10.5(22.2)$ & - & - & - \\
\hline Jun & $28.1(5.4)$ & $7.5(15.9)$ & $9.9(29.7)$ & $4.9\{20.0\}$ & $13.3(7.3)$ & $21.4(11.1)$ \\
\hline Jul & $61.8(4.0)$ & $47.2(14.7)$ & $258(7.9\}$ & $19.6(2.3)$ & $29.1(10.2)$ & $12.0(5.1)$ \\
\hline Aug & $19.4(5.8)$ & $15.9(3.4)$ & $15.7(4.1)$ & $32.1(1.4)$ & $20.5(1.0)$ & $32.1(2.5)$ \\
\hline Sep & $4.5(10.5)$ & $21.6(5.2)$ & $15.7(4.8)$ & $12.5(0.9)$ & $15.2(1.3)$ & $17.6(1.2)$ \\
\hline Oct & $6.6(10.6)$ & $15.7(4.0)$ & $20.3(1.1)$ & $8.4(2.6)$ & $32.2(0.4)$ & $26.4(0.9)$ \\
\hline Dec & $0.4(3.4)$ & $4.8(0.6)$ & $5.8(2.0)$ & $1.6(5.8)$ & $6.0(1.0)$ & $2.9(3.2)$ \\
\hline
\end{tabular}
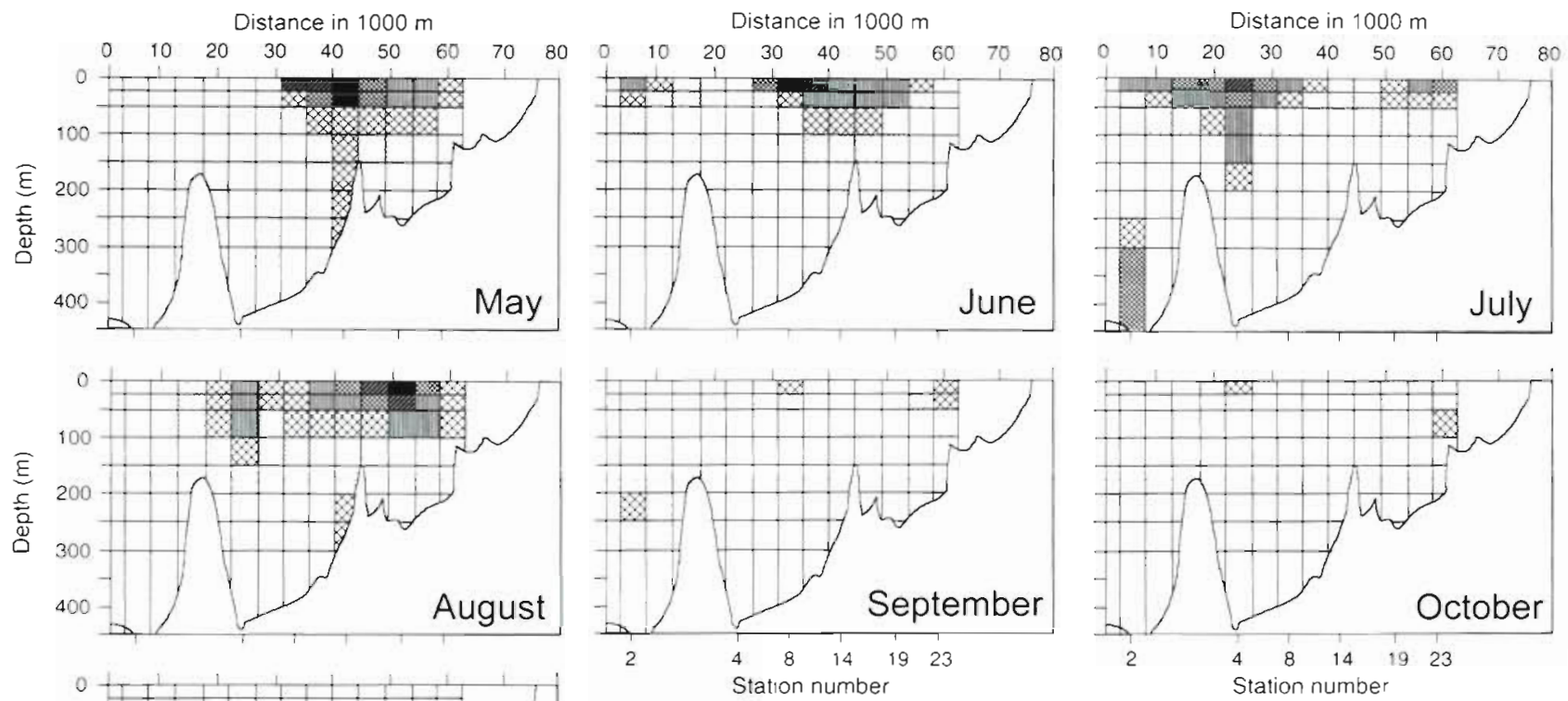
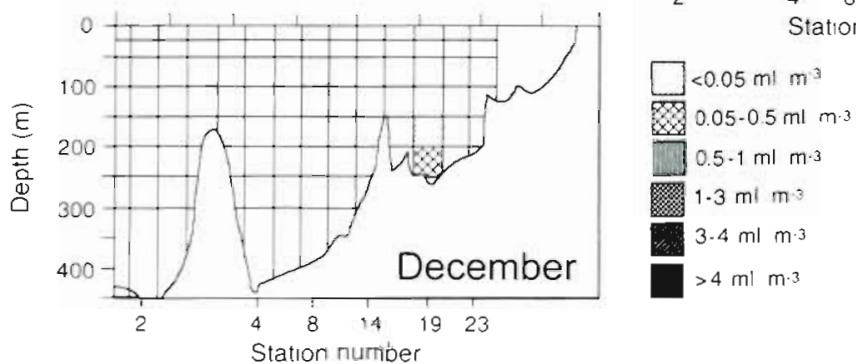

proportions of the biomass were located in the upper $50 \mathrm{~m}$ in spring and early summer $(20$ to $60 \%$ in April to June). During fall. and winter, 90 to $100 \%$ of the biomass was found below $50 \mathrm{~m}$.

\section{Ctenophores}

Ctenophores caught in the WP3 were in good condition. However, the volume of water filtered at each vertical tow was low $\left(20\right.$ to $\left.50 \mathrm{~m}^{3}\right)$, and the vertical resolution was poor. The water column at each station
Fig. 3. Bolinopsis infundibulum. Vertical distribution $(\mathrm{ml}$ wet volume $\mathrm{m}^{-3}$ ) along the sampling axis in Malangen from May to December 1992

was sampled only once with the WP3, and due to the patchy distribution of ctenophores, catches in the WP3 were variable and could not be treated statistically. For this reason, net tow samples were only used for analyzing size distributions of ctenophores. Much of the ctenophore biomass was lost from the MOCNESS samples due to fragmentation of animals. This was especially the case for Bolinopsis infundibulum, which is more fragile than Beroe cucumis. On average, the estimated biovolumes of $B$. infundibulum per $\mathrm{m}^{2}$ based on WP3 samples were 4 times larger than the estimates from MOCNESS samples (WP3:MOCNESS ratio $4 \pm$ 

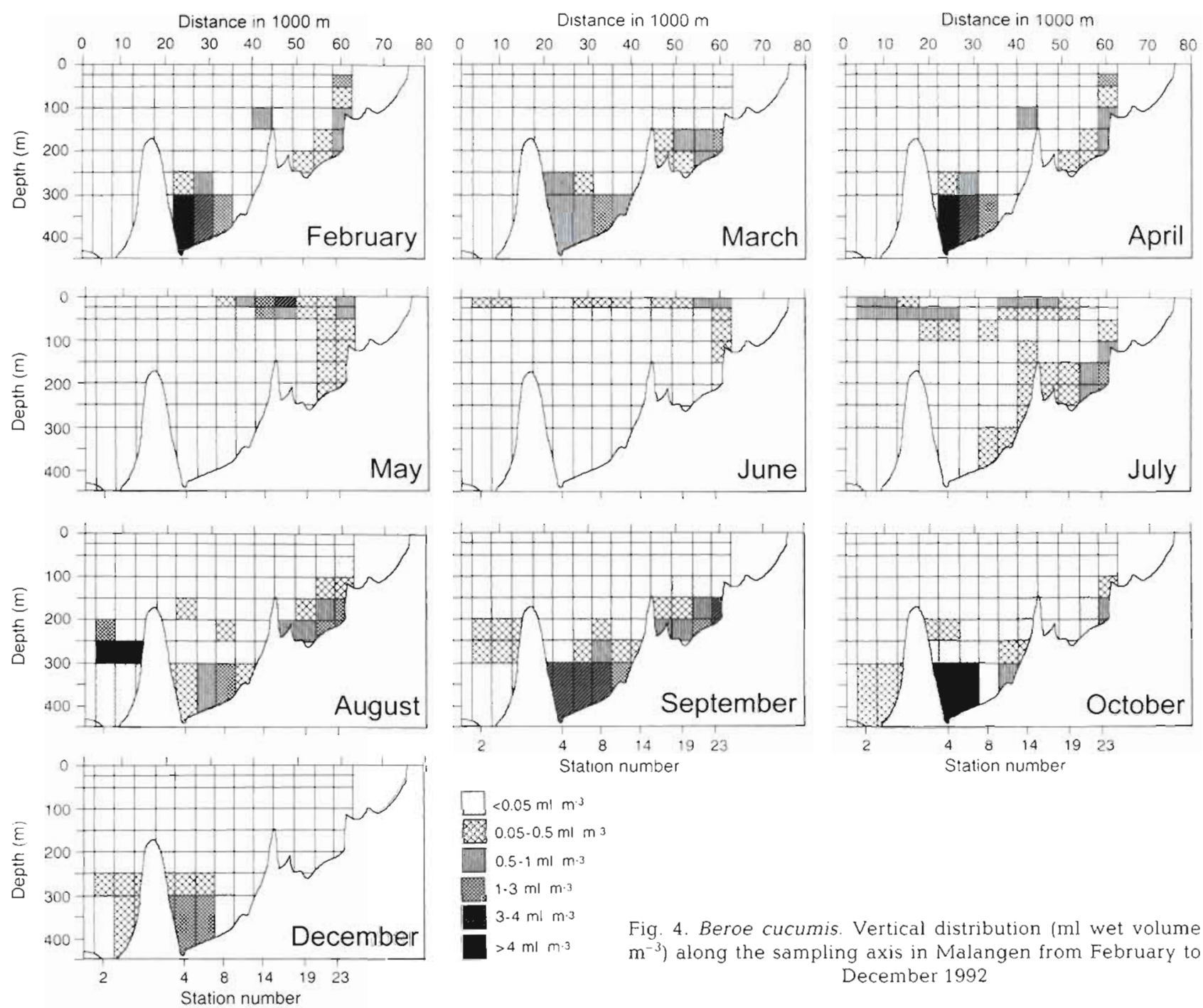

Fig. 4. Beroe cucumis. Vertical distribution (ml wet volume $\mathrm{m}^{-3}$ ) along the sampling axis in Malangen from February to December 1992

2.9). The ratio was however not significantly different from $1(p>0.05)$, due to the variability in WP3 catches. The losses are considered to be variable with depth, due to differences between nets in tow lengths and clogging. However, the distribution of $B$. infundibulum was restricted to the upper $50 \mathrm{~m}$ (which was confirmed by the WP3 net sampling) and the duration of the surface sampling ( 50 to $0 \mathrm{~m}$ ) was less than $5 \mathrm{~min}$. Thus, the biovolumes of $B$. infundibulum are underestimates, but are assumed to mirror variations in the seasonal, horizontal and vertical distributions for this species.

Very few Bolinopsis infundibulum occurred in the MOCNESS samples from February to April (less than $0.004 \mathrm{ml} \mathrm{m}^{-3}$, not shown in figures). An increase in biovolumes of $B$. infundibulum occurred from April to May, when high concentrations (>4 $\mathrm{ml} \mathrm{m}^{-3}$ ) were found in the upper $20 \mathrm{~m}$ layer (Fig. 3). The ctenophores appeared earlier in the inner part of the fjord, and maximum volumes were found further out in the fjord as the season proceeded (Fig. 3). The biovolumes of $B$. infundibulum reached maximum values in June, and from August on, they decreased, reaching very low levels in December $B$. infundibulum was almost absent during the winter, while large volumes of Beroe cucumis (>4 $\mathrm{ml} \mathrm{m}^{-3}$; Fig. 4) were present in the deeper basins of the fjord (below $200 \mathrm{~m}$ ) during winter and fall (February to April and August to December). During the summer period (May to July), volumes of $B$. cucumis were lower, and the major part of its population was situated above $50 \mathrm{~m}$, usually within or just below the layer of its prey, $B$. infundibulum. No differences were found in the vertical distribution of ctenophores between day and night.

Three patterns for seasonal variations of ctenophore biovolume and zooplankton biomass are shown in Fig. 5: for Stn 2 (outside the sill), Stn 8 (inside the sill) and Stn 23 (fjord head). At all 3 stations, Bolinopsis infundibulum appeared during the period when bio- 


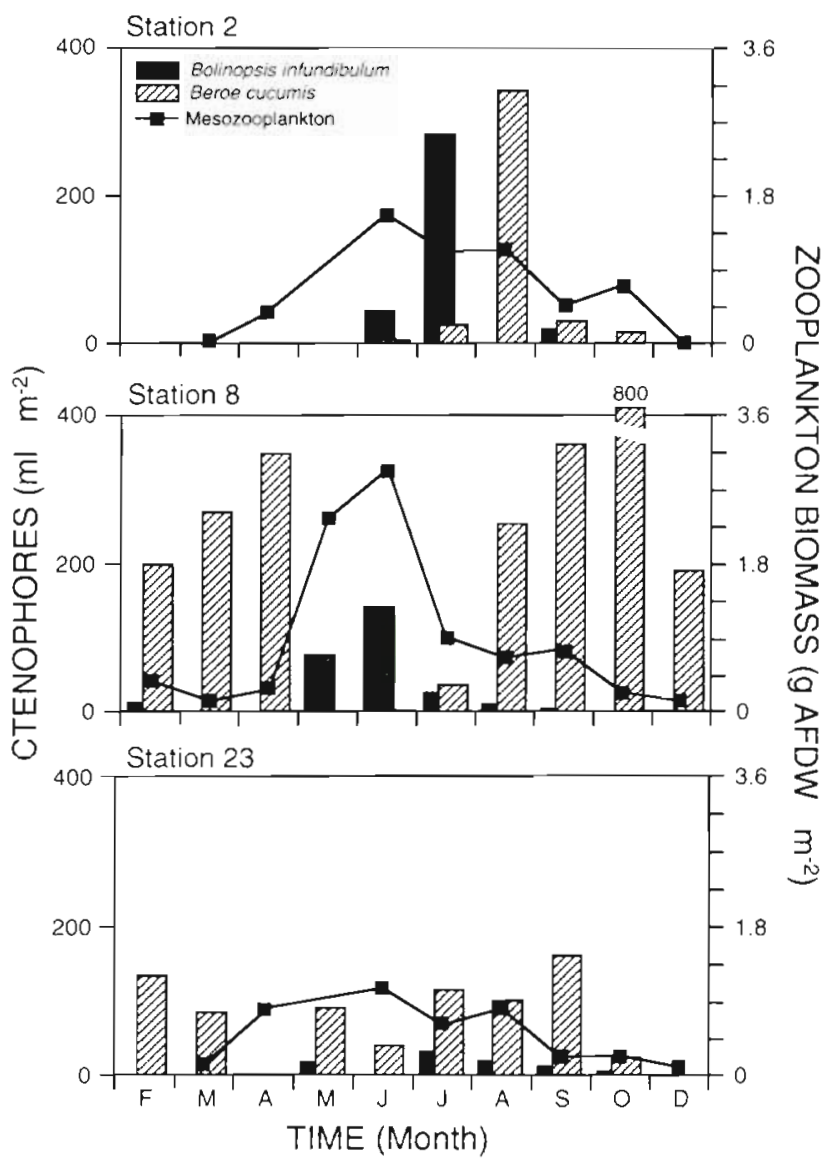

Fig. 5. Seasonal variations in Bolinopsis infundibulum (m] $\left.\mathrm{m}^{-2}\right)$, Beroe cucumis $\left(\mathrm{ml} \mathrm{m} \mathrm{m}^{-2}\right)$, and mesozooplankton biomass (m) AFDW $\mathrm{m}^{-2}$ in $0-50 \mathrm{~m}$ ) outside the sill (Stn 2), unside the sill (Stn 8), and fjord head (Stn 23)

masses of mesozooplankton above $50 \mathrm{~m}$ were high (May to August). The peak in B. infundibulum appeared somewhat earlier at the inner station (in June at $\operatorname{Stn} 8$ ) compared to the outer station (in July at Stn 2). At the outer station (Stn 2), Beroe cucumis was absent during the winter, but appeared in June, and a peak was reached after the decrease of $B$. infundibulum, in August. Within the fjord, B. cucumis was present mast of the year At the deeper Stn 8 , volumes of $B$. Cucumis were high during the winter $\left(>790 \mathrm{ml} \mathrm{m}^{-2}\right)$ but low in summer $\left(<45 \mathrm{ml} \mathrm{m}^{-2}\right)$ when $B$. infundibulum was abundant. At the fjord head (Stn 23) B. cucumis was present all year, at fairly constant volumes (45 to $150 \mathrm{ml} \mathrm{m} \mathrm{m}^{-2}$, and volumes of $B$. infundibulum were always low $\left(<45 \mathrm{ml} \mathrm{m}^{-2}\right)$

The vertical distributions of ctenophores and their prey was found to have 2 basic patterns, illustrated by the fall/winter period (Fig. 6a) and the late spring/early summer period (Fig. 6b) at Stn 8. In the fall/winter period, the stability of water masses was low, and the major part of the mesozooplankton biomass (>500 $\mu \mathrm{m})$
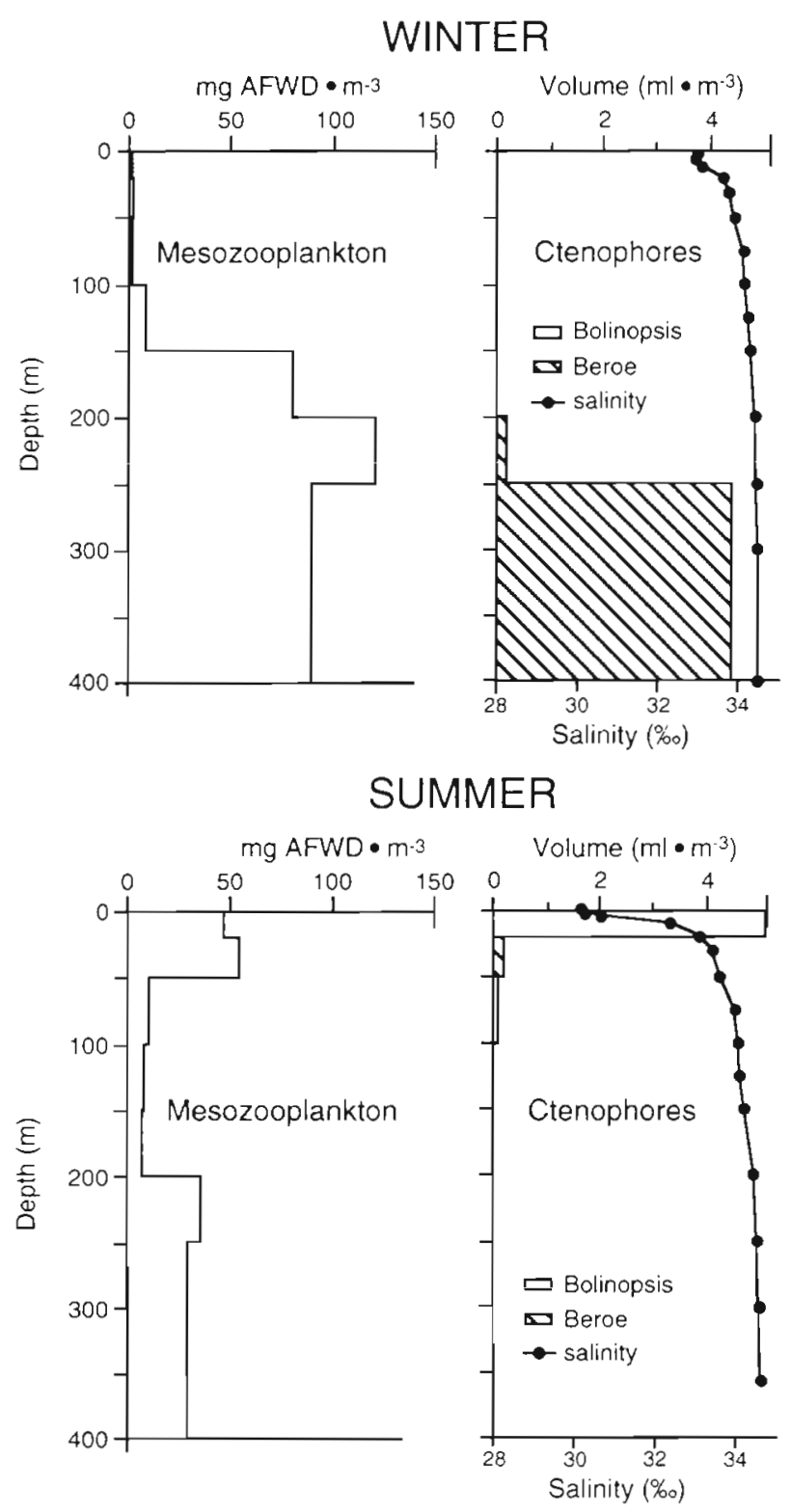

Fig. 6. Vertical distributions of zooplankton and ctenophores in Malangen during (a) winter and (b) summer. Left panel: Mesozooplankton biomass (mg AFDW $\mathrm{m}^{-3}$ ). Right panel: Bolinopsis infundibulum, Beroe cucumıs, and density $\left(\sigma_{t}\right)$

was found below $150 \mathrm{~m}$. Bolinopsis infundibulum was present in very low numbers (not visible in the figure), and high volumes of Beroe cucumis $\left(6 \mathrm{ml} \mathrm{m}^{-3}\right)$ were found in deeper waters, below $250 \mathrm{~m}$ (Fig. 6a). The summer situation (Fig 6b) was characterized by a halocline at 20 meters, and a bimodal vertical distribution of mesozooplankton biomass. Large volumes of $B$. infundibulum $\left(6.5 \mathrm{ml} \mathrm{m} \mathrm{m}^{-3}\right)$ occurred above $20 \mathrm{~m}$. B cucumis was found within or just below the layer of its prey, increasing in volume from May $\left(<0.5 \mathrm{ml} \mathrm{m}^{-3}\right)$ to June ( $>1 \mathrm{ml} \mathrm{m}^{-3}$ ). 

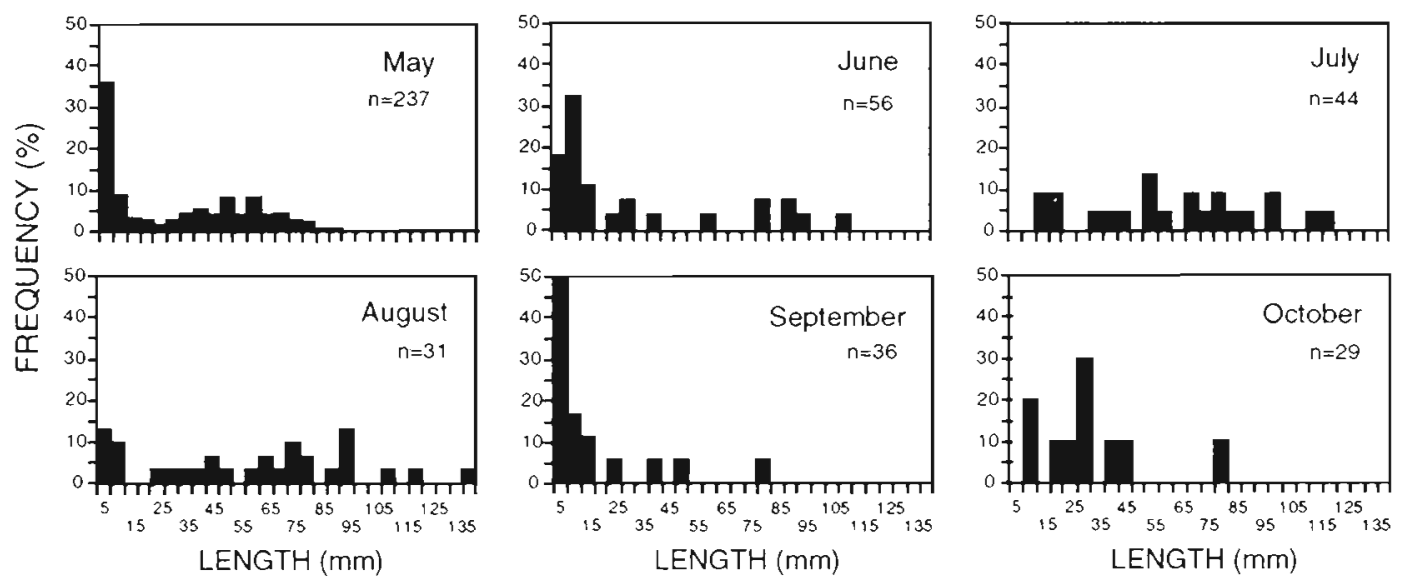

Fig. 7 Bolinopsis infundibulum. Length frequency distributions of specimens captured in WP-3 net, May to October 1992. $\mathrm{n}=$ number of specimens measured

\section{Length frequency distributions}

The coarse mesh size used in this study excluded the smallest and youngest ctenophore offspring from the analysis ( $<1 \mathrm{~mm}$ ). Rapid growth when food availability is optimal, and the ability to shrink when food supplies are scarce, make it difficult to follow cohorts of gelatinous zooplankton. The size frequency distributions from Malangen (Figs. 7 \& 8) must thus be interpreted with caution, but are assumed to indicate periods of reproduction and growth: the frequency distributions of Bolinopsis infundibulum (Fig. 7) were bimodal in May and June, which was interpreted as 2 different cohorts. A large proportion of small individuals (<10 mm) were found in May, June and September, indicating periods of high production of offspring. The maximum size found in the samples increased from May (90 mm) to August (140 mm).

The size distributions of Beroe cucumis were unimodal throughout the year, but demonstrated different shapes in summer and winter (Fig. 8): the winter distribution (February to April and September to December) was characterized by a peak at 20 to $30 \mathrm{~mm}$ length, and some individuals were more than $100 \mathrm{~mm}$ long. In the summer (May to August), most individuals were small ( 5 to $10 \mathrm{~mm}$ ). This was interpreted as the appearance of a new cohort of small individuals, which coincided with the decline in numbers of large individuals $>80 \mathrm{~mm}$

\section{DISCUSSION}

\section{Seasonal variations of ctenophores}

During the winter, very few specimens of Bolinopsis infundibulum were found in Malangen. The source of the seed population of ctenophores is an unresolved question in many areas, but the species is often assumed to overwinter in the water column in small numbers (Bigelow 1926, Fraser 1970). In the present study, the total volumes filtered during the first 3 cruises (February, March and April) were 5700, 7000, and $8600 \mathrm{~m}^{3}$, respectively (average $664 \mathrm{~m}^{3}$ per station). Despite the large volumes filtered, only a single specimen of $B$. infundibulum was caught during this period (February, 100 to $150 \mathrm{~m}$ depth at $\operatorname{Stn} 8$ ). The density of the seeding population in this species may thus be less than 1 individual $(20 \mathrm{ml})$ per $5700 \mathrm{~m}^{3}$. Similarly, low numbers ( 1 to 2 ind. per $104 \mathrm{~m}^{3}$ ) of the related species Mnemiopsis leidyi were found to overwinter in Narragansett Bay (Rhode Island, USA) (Kremer 1976). However, no winter population of $M$. leidyi was found in the Barnegat estuary (New Jersey, USA), but adults were tidally inoculated from colder coastal waters in the spring (Nelson 1925, Mountford 1980). Increased survival of ctenophores as a result of anomalously high sea temperatures were responsible for high spring abundances of Pleurobrachia pileus in waters off southwestern Nova Scotia, Canada (Frank 1986). No individuals of $B$. infundibulum were found outside the fjord sill of Malangen during the winter. However, $B$. infundibulum was observed ( 1 to $3 \mathrm{ind}$. per $10 \mathrm{~m}^{3}$ ) all winter in a shallow semi-enclosed bay near Malangen (author's unpubl. data). Open waters are more exposed to turbulence, and one would expect the overwintering of this delicate species to be more successful in sheltered areas along the coast.

The predator Beroe cucumis was found to overwinter in the deeper basins of Malangen from September to April. High concentrations of the ctenophore were found below $250 \mathrm{~m}$ in the fjord ( $\operatorname{Stn} 8$, Fig. 4) where the advective impact is low (Falkenhaug et al. 1995). Outside the fjord sill, volumes of $B$. cucumis were much 

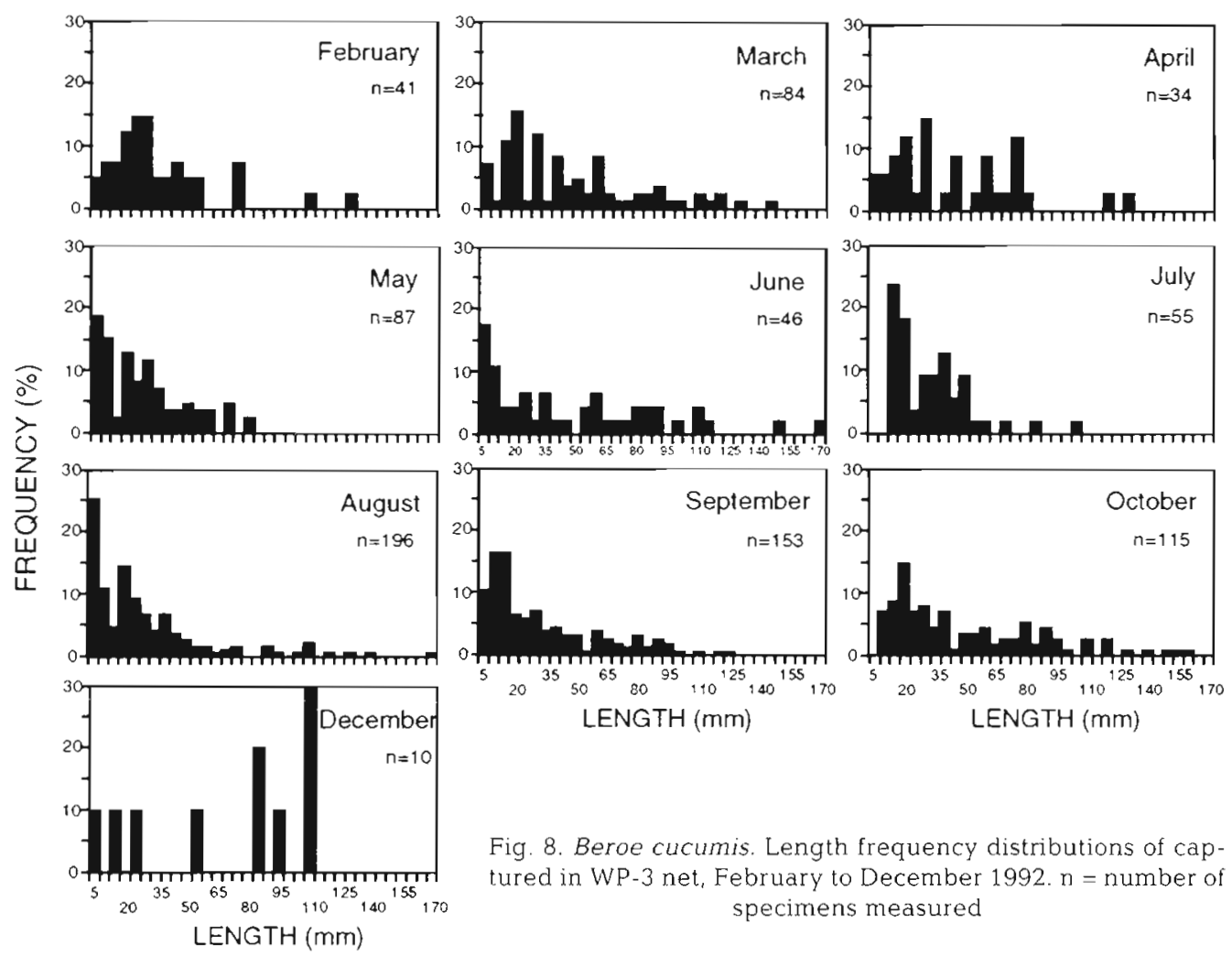

Fig. 8. Beroe cucumis. Length frequency distributions of captured in WP-3 net. February to December 1992. $n=$ number of specimens measured

lower during the winter (Stn 2, Figs. $4 \& 5$ ). The most dense samples of $B$. cucumis during winter were obtained when the MOCNESS incidentally touched the bottom. The fate of Beroe populations during the winter is scarcely described in the literature, since populations located close to the bottom may be difficult to catch with traditional plankton sampling gear. Overwintering in deeper water layers has been reported for $B$. ovata and the cydippid Mertensia ovum in the Canadian Arctic (Siferd \& Conover 1992), while B. cucumis is thought to immigrate into the Bay of Fundy, Canada (Milne \& Corey 1986). In the Canadian Arctic, peaks in the abundance of $B$. ovata and $M$. ovum coincided, which is unusual for predator-prey relationships. Similarly, a closer match between predator and prey was observed at the innermost station in Malangen (Stn 23, Fig. 5). At this station, the biomass of $B$. cucumis was constant most of the year, and no distinct peak in the biomass of $B$. infundibulum was observed. A large overwintering population will ensure early spawning and a close match between predator and prey.

In early summer, rapid changes in biovolumes of ctenophores were observed, which is characteristic of gelatinous zooplankton populations (Kremer \& Nixon 1976, van der Veer \& Sadee 1984, Larson 1986). Stabilization of water masses, increased water temperatures and abundant food supplies triggered rapid reproduc- tion of Bolinopsis infundibulum in May (Fig. 7). Stratification of water masses started earlier, and was most pronounced in the inner part of the fjord (Fig. 2) where the ctenophores start to reproduce in the spring. The sampling frequency in this study was too low to resolve the dynamics of the increase in biomass of $B$. infundibulum in spring However, the biovolume increased from zero to $90 \mathrm{ml} \mathrm{m}^{-2}$ in $7 \mathrm{wk}$ (April and May). During the next 2 wk (May 27 to June 10) the biomass of $B$. infundibulum increased by more than $200 \%$ at some stations. Its self-fertilization potential, extremely high fecundity, and rapid growth potential explain how the population can increase at such high rates within a few weeks.

Overwintering adults of Beroe cucumis probably spawned when their prey Bolinopsis infundibulum occurred in April and May, as was indicated by the change in size frequency distributions (Fig. 8). Large overwintering individuals disappeared from the fjord in May, as illustrated by a decrease in biomass of $B$ cucumis at Stn 8 (Fig. 5) and a decrease in mean length in May (Fig. 8). The biomass of B. cucumis increased in Malangen in July, and its abundance peaked after that of $B$. infundibulum. This typical time lag between Beroe and its prey also has been described by Greve \& Reiners (1988).

The zooplankton in Malangen is highly influenced by advective processes (Falkenhaug et al. 1995). In 
Table 3. Daily advective transport of ctenophores and zooplankton biomass in May and October 1992, expressed as \% of content inside the fjord. A negative 'Net' transport value indicates that net transport is directed out of the fjord. Calculations are based on current data in Falkenhaug et al. (1995)

\begin{tabular}{|c|c|c|c|c|c|c|}
\hline & \multicolumn{3}{|c|}{ May } & \multicolumn{3}{|c|}{ October } \\
\hline & $\ln$ & Out & Net & In & Out & Net \\
\hline Mesozooplankton & 5.1 & 4.2 & 0.9 & 0.4 & 1.4 & -1.0 \\
\hline \multicolumn{7}{|l|}{ Ctenophora } \\
\hline Bolinopsis infundibulum & 0.3 & 58 & -58 & 0 & 0 & 0 \\
\hline Beroe cucumis & $<0.1$ & 55 & -55 & 0 & $<0.1$ & $<0.1$ \\
\hline
\end{tabular}

\section{Vertical distribution of ctenophores and copepods}

In the Malangen area, the sun stays below the horizon from 28 November until 14 January, and above the horizon from 19 May until 26 July. Bolinopsis infundibulum occurred during the midnight sun period with little diel variation. During this period, ctenophores and a large proportion of the mesozooplankton were found above $50 \mathrm{~m}$, with no diel variations in the vertical distributions. The seasonal

advective systems, the change in abundance of a species at a given site may not be related to biological processes, but rather be a consequence of an exchange of water mass containing different populations (Schneider 1987). The daily advective transport of zooplankton biomass and ctenophores is calculated in Table 3 from current velocities presented in Falkenhaug et al. (1995). The main circulation pattern in Malangen involved strong outgoing currents in the surface layers through the fjord mouth (Stn 8) and weak counter currents below. In the two narrow sounds (Stns 12 and 26) currents above sill level were directed into the fjord. Due to their shallow vertical distribution, Bolinopsis infundibulum and Beroe cucumis were transported out of the fjord at a daily rate equivalent to 55 and $58 \%$ of their standing stocks. respectively. The fjord was thus providing adjacent waters with ctenophore biomass in this period. This agrees with the observation that the peak in ctenophore abundance was found later in the open waters outside the fjord compared with the inner part of the fjord (Fig. 5). The spreading of the population within the fjord system can be described as prey-predator waves (Greve \& Reiners 1980). Even though the horizontal distribution of ctenophores was affected by advection, this is not assumed to affect the interactions and relative abundances of $B$. infundibulum and $B$. cucumis, since both species were distributed within the same current layer. In the fall, $B$. cucumis was abundant, but due to the deep distribution below sill level (Figs. $4 \& 6 a$ ), the advective rates of this species were very low. By overwintering in deeper waters, $B$. cucumis avoids the effect of higher current velocities in the fall and winter, and remains in the system until $B$ infundibulum appears the next spring.
Table 4. Predation impact of Bolinopsis infundibulum and Beroe cucumis on their prey populations. Carbon ingested per day as \% of prey carbon standing stock. Metabolic demand calculated from carbon-specific respiration $3 \%$ of body carbon per day in B. infundibulum (Barley et al. 1994) and $8 \%$ per day in Beroe ovata (Kremer et al. 1986a)]. Assumptions: assimilation efficiency $=75 \%$ (Reeve et al. 1978); DW in ctenophores $=4 \%$ of WW carbon content in $B$. infundibulum calculated from regressions in Bailey et al. (1994). Carbon content in B. cucumis $=9 \%$ of DW (Ikeda \& Mitchell 1982). Carbon content in zooplankton = A.FDW $\times$ $0.547 / 0.831$ (Båmstedt 1986). Predation rate of B. infundibulum calculated by applying clearance rate in Bolinopsis vitrea $\left(14.5 \mathrm{l} \mathrm{mg}^{-1} \mathrm{C} \mathrm{d}^{-1}\right.$; Kremer et al. $\left.1986 \mathrm{~b}\right)$

\begin{tabular}{|lcccccc|}
\hline \multicolumn{3}{l}{ Depth strata (m) } & \multicolumn{3}{c}{ Metabolic demand } & \multicolumn{3}{c|}{$\begin{array}{c}\text { Predation } \\
\text { June }\end{array}$} & July & August & June & July & August \\
\hline Bolinopsis infundibulum & & & & & \\
$0-20$ & 0.4 & 0.9 & 0.5 & 7.3 & 2.3 & 4.1 \\
$20-50$ & 0.1 & 0.0 & 0.0 & 1.3 & 0.0 & 0.0 \\
50 -bottom & $<0.01$ & $<0.01$ & $<0.01$ & 0.1 & 0.03 & 0.2 \\
Total & 0.1 & 0.02 & 0.02 & 1.3 & 0.35 & 0.69 \\
Beroe cucumis & & & & & & \\
$0-20$ & 4.7 & 6.4 & 0.0 & & & \\
$20-50$ & 6.9 & 0.0 & 0.0 & & & \\
50-bottom & 15 & 810 & 240 & & & \\
Total & 5.5 & 47 & 35 & & & \\
\end{tabular}


The calculated metabolic demand of $B$. infundibulum is equivalent to 0.4 to $0.9 \%$ of the standing stock of zooplankton carbon in the upper $20 \mathrm{~m}$ in the period June to August. Applying a clearance rate for the closely related Bolinopsis vitrea $\left(14.5 \mathrm{l} \mathrm{mg}^{-1} \mathrm{C} \mathrm{d}^{-1}\right.$; Kremer et al. 1986b), the ingestion by $B$. infundibulum in June to August equals 2 to $7 \%$ of the zooplankton carbon in the upper $20 \mathrm{~m}$, and 0.4 to $1 \%$ of the zooplankton carbon in the total fjord. These values are low compared with other studies in which ctenophores were found to affect their prey populations (Bishop 1967. Deason \& Smayda 1982, Williams \& Collins 1985). However, due to loss during net sampling, the calculated ingestion by $B$. infundibulum in this study is underestimated. Miller \& Daan (1989) found no significant impact of Pleurobrachia pileus on copepods off the Dutch coast. Nevertheless, models have shown that predatory control can occur even at moderate consumption rates (Davis 1984). However, in an advective system, planktonic predators are not a part of the usual predator-prey relationship as described by the LotkaVolterra equations (Aksnes et al. 1989). No significant correlation between volumes of $B$. infundibulum and mesozooplankton biomass ( $p>0.05$ ) was found. The advective exchange of mesozooplankton biomass in Malangen was found to be $9 \%$ of the mesozooplankton standing stock per day in May and June (Table 3), which exceeded the calculated predatory impact by $B$. infundibulum $(1.3 \%$, Table 2$)$ in this period. The sampling volumes used here were large in order to overcome the patchy nature of the ctenophores. On such a scale however, biological factors such as predation may be overriden by physical factors.

The factor most often cited as affecting the seasonal abundance of gelatinous predators is prey abundance (Greve 1971, Kremer 1976, Deason \& Smayda 1982. Larson 1986). The decrease in the population of Bolinopsis infundibulum coincided with the seasonal decrease in mesozooplankton biomass above $50 \mathrm{~m}$ (e.g. $70 \%$ decrease at Stn 8 from June to September; Table 2, Fig. 5). The total mesozooplankton biomass in the fjord continued to increase until late fall, but only a small proportion remained in the surface layer all year However the biomass found within the layer of $B$. infundibulum (above $50 \mathrm{~m}$ ) in late fall and winter, would not be sufficient to substain a large population of $B$. infundibulum. The proportion of $B$. infundibulum caught with empty guts increased from $63 \%$ in May and June to $80 \%$ in July and August (author's unpubl. data). In September no individuals were found with prey in their guts, which indicates food limitation in the fall.

Species of Beroe are often associated with the decline of populations of other ctenophores (Greve 1971, Hirota 1974, Swanberg \& Bămstedt 1991). The metabolic demand of B. cucumis in Malangen was calculated (Table 4) on the assumption that the carbonspecific respiration was $8 \%$ per day (Kremer et al. 1986a). The minimum impact of $B$. cucumis on Bolinopsis infundibulum was low at the beginning of the season $(5.9 \%)$, but increased to $50 \%$ in July. Predation by $B$. cucmis thus contributed to the decrease in $B$ infundibulum in late summer. Amorphous material, presumably ctenophores, was found in cod stomachs during the winter in Malangen and during the summer in other northern Norwegian fjords ( $T$. Pedersen pers comm.). Cod, which has been reported to feed on ctenophores in arctic waters (Boldovsky 1944, Hansen 1949), may thus be a significant predator on both $B$ infundibulum and $B$. cucumis in the study area. The role of fish as predators on gelatinous zooplankton has probably been underestimated, and more quantitative work is needed on this interaction (Arai 1988). The scyphozodn Cyanea capillata, which is known to feed on ctenophores (Purcell 1991, Siferd \& Conover 1992), peaked in the fall (September to October, pers. obs.) after the decrease in biomass of $B$. infundibulum, and might not be an important ctenophore predator in this area. The fragile $B$. infundibulum is sensitive to strong water movements. Currents and winds were stronger in the fall (Falkenhaug et al. 1995), and the decrease in water stability from July onward (Fig. 3) coincided with the decrease in biovolumes of $B$. infundibulum (Fig. 6). The fall decline in the population of $B$. infundibulum was probably caused by the combination of decreased growth, due to low prey abundance, and increased mortality, due to predation and water turbulence.

The fall and winter biomass of Beroe cucumis was high, in spite of the absence of Bolinopsis infundibulum (Figs. 4 \& 5). My data suggest that B. cucumis may not be totally dependant on the availability of $B$ infundibulum. The population of $B$. cucumis would lack adequate amounts of prey during most of the year (September to April) if the metabolic demand $(8 \%)$ remained constant and if $B$. infundibulum were the only food source. Pleurobrachia pileus has only been observed occasionally in this area, and could not support the large winter population of $B$. cucumis. There are copepods, Cyanea capillata, Aurelia aurita and a number of hydromedusae available in Malangen on which $B$. cucumis could potentially predate. However, I was unable to make $B$. cucumis feed on crustacean prey, A. aurita, or Rathkea octopunktata in the laboratory, and no prey items were found in guts of $B$. cucumis during the winter Ctenophores are able to undergo periods of food shortage or absence by utilizing their own body tissue for their metabolic requirements and so gradually shrink in size (Kamshilov 1960, Kremer 1976). However, the length frequency distribu- 
tions (Fig. 8) showed no decrease in size of $B$. cucumis during fall and winter. On the contrary, mean size increased from $29 \mathrm{~mm}$ in August to $70 \mathrm{~mm}$ in December. The nutritional source of $B$. cucumis during the winter remains unidentified

In summary, the seasonal dynamics of Bolinopsis infundibulum and Beroe cucumis were characterized by alternating abundances of the 2 ctenophore species. Large volumes of $B$. cucmis were present in the fjord during the winter months when $B$. infundibulum was absent. A time lag in the reproductive response of $B$ cucumis on the appearance of its prey made a 'window' in time of decreased predation risk (May to July) within which the population of $B$. infundibulum was able to reproduce and reach high abundances.

Acknowledgements. I am grateful to the captain and crew of RV 'Johan Ruud' for their cooperation and assistance. I thank J. T. Eilertsen, K. Lydersen and U. Normann for technical support during the cruises, and A. Arentsen, G. A. Hansen, E. Nordby, S. Jorgensen, G. Ottesen and U. Zeller for help during sampling. Figures were drawn by Fraydis Strand. This work was funded by the Norwegian Research Council through project \#101703/720. I thank K. Tande and 3 anonymous reviewers for their helpful comments

\section{LITERATURE CITED}

Aksnes DL, Aure J, Kaartvedt S, Magnesen T, Ruchard J (1989) Significance of advection for the carrying capacities of fjord populations. Mar Ecol Prog Ser 50:263-274

Arai MN (1988) Interactions of fish and pelagic coelenterates. Can J Zool 66:1913-1927

Bailey TG, Youngbluth MJ, Owen GP (1994) Chemical composition and oxygen consumption rates of the ctenophore Bolinopsis infundibulum from the Gulf of Maine. J Plankton Res 16:673-689

Baker LD (1973) Ecology of the ctenophore Mnemiopsis mccradyi Mayer, in Biscayne Bay, Florida. Rosenstiel School of Marine and Atmospheric Science, University of Miami, Technical Report UM-RSMAS-73016

Bigelow HB (1926) Plankton of the offshore waters of the Gulf of Maine. Bull Bur Fish Wash 40, 509 p

Bishop JW (1967) Feeding rates of the ctenophore Mnemiopsis leidyi. Chesapeake Sci 8:259-261

Bogorov BG (1946) Peculiarities of diurnal vertical migrations of zooplankton in polar seas. J Mar Res 6:26-32

Boldovsky GV (1944) The food of the Norway haddock in the Barents Sea. Tr Polyarn Nauchno-Issled Proektn Inst Morsk Rybn Khoz Okeanogr 8:307-330 (in Russian)

Buchanan C. Haney J (1980) Vertical migrations of zooplankton in the Arctic: a test of the environmental controls. In: Kerfoot WC (ed) Evolution and ecology of zooplankton communities. University Press of New England, Hanover, $\mathrm{NH}, \mathrm{p} 69-79$

Båmstedt U (1986) Chemical composition and energy content. In: Corner EDS, O'Hara SCM (eds) The biological chemistry of marine copepods. Clarendon Press, Oxford, p 1-58

Davis CS (1984) Predatory control of copepod seasonal cycles on Georges Bank. Mar Biol 82:31-40

Deason EE, Smayda TJ (1982) Ctenophore-zooplanktonphytoplankton interaction in Narragansett Bay, Rhode Island, USA during 1972-1977. J Plankton Res 4:203-217
Falkenhaug T, Nordby E, Svendsen H, Tande K (1995) Impact of advective processes on displacement of zooplankton biomass in a North Norwegian fjord system. A comparison between spring and autumn. In: Skoldal HR, Hopkins CCE, Erikstad KE, Leinaas HP (eds) Ecology of fjords and coastal waters. Proceedings of the Mlare Nor Symposium on the Ecology of Fjord and Coastal Waters, Tromsø, Norway, 5-9 December 1994. Elsevier, Amsterdam, p $195-217$

Frank KT (1986) Ecological significance of the ctenophore Pleurobrachia plleus oft southwestern Nova Scotia. Can J Fish Aquat Sci 43:211-222

Fraser JH (1970) The ecology of the ctenophore Pleurobrachia pileus in Scottish waters. $J$ Cons int Explor Mer 33: $149-168$

Gamble JC (1974) Preliminary observations on the feeding of Bolinopsis infundibulum. Comm Meet Int Coun Explor Sea ICES CM, 1974/L:14, Plankton Comm 8 p

Gamble JC (1977) Population structure, feeding behavior, and fecundity of the lobate ctenophore, Bolinopsis infundibulum. Comm Meet Int Coun Explor Sea ICES CM 1977/L:16

Greve W (1970) Cultivation experiments on North Sea ctenophores. Helgoländer Wiss Meeresunters 20:304-317

Greve W (1971) Ökologische Untersuchungen an Pleurobrachia pileus. I. Freilanduntersuchungen. Helgoländer Wiss Meeresunters 22:303-325

Greve W (1981) Invertebrate predator control in a coastal ecosystem: the significance of Beroe gracilis (Ctenophora). Kieler Meeresforsch, Sonderh 5:211-217

Greve W, Reiners F (1980) The impact of prey-predator waves from estuaries on the planktonic marine ecosystem. In: Kennedy VS (ed) Estuarine perspectives. Academic Press, New York, p 405-421

Greve W. Reiners F (1988) Plankton tıme-space dynamıcs in German Bight - a systems approach. Oceologia 77 : $487-496$

Gröndahl F, Hernroth L (1986) Vertical distribution of copepods in the eurasian part of the Nansen Basin. Arctic Ocean. In: Schriever G, Schminke HK, Shih CT (eds) Proceedings of the 2nd International Conference on Copepoda, Ottawa Syllogeus No. 58, Ottawa, p 311-320

Hansen PM (1949) Studies on the biology of the cod in Greenland waters. Rapp PV Réun Comm Int Explor Mer 123: $1-77$

Harbison GR, Madin LP, Swanberg NR (1978) On the natural history and distribution of oceanic ctenophores. Deep Sea Res 25:233-256

Hirota J (1974). Quantitative natural history of Pleurobrachia bachei in La Jolla Bight. Fish Bull US 72:295-335

lkeda T, Mitchell AW (1982) Oxygen uptake, ammonı excretion and phosphate excretion by krill and other antarctic zooplankton in relation to their body size and chemical composition. Mar Biol 71:283-298

Kamishlov MM (1960) Feeding of ctenophore Beroe cucumis. Dokl Akad Nauk SSSR 130:1138-1140

Kamishlov MM, Zelikman EA, Roukhivainen MI (1958) Plankton of the coastal zone of the Murman. In: Natural phenomenon in aggregations and migrations of fish in the coastal zone of the Murman and its relation with biological, hydrological and hydrochemical processes. Akademie Nauk SSSR, Moscow-Leningrad, p 59-102 (in Russian)

Kremer JN, Nixon SW (1976) A coastal marine ecosystem. Simulation and analysis. Springer-Verlag, New York

Kremer PM (1976). Population dynamics and ecological energetics of a pulsed zooplankton predator, the ctenophore Mnemiopsis leidyi. In: Wiley ML (ed) Estuarine processes, 
Vol 1. Academic Press, New York, p 197-215

Kremer PM (1979) Predation by the ctenophore Mnemiopsis Leidyl in Narragansett Bay, Rhode Island. Estuaries 2: $97-105$

Kremer PM, Canino MF, Gilmer RW (1986a) Metabolism of epipelagic tropical ctenophores. Mar Bıol 90:403-412

Kremer PM, Reeve MR, Syms MA (1986b) The nutritional ecology of the ctenophore Bolinopsis vitrea: comparisons with Mnemiposis mccradyi from the same region. J Plankton Res 8:1197-1208

Larson RJ (1986) Seasonal changes in standing stocks, growth rates, and production rates of gelatinous predators in Saanich Inlet, British Columbia. Mar Ecol Prog Ser 33: $89-98$

Lenz $J$ (1973) On the occurence of the ctenophore Bolinopsis infundibulum (O.F.Müller) in the Western Baltic. J Cons Int Explor Mer 35:32-35

Miller RJ, Daan R (1989) Planktonic predators and copepod abundance near the Dutch coast. J Plankton Res 11 263-282

Milne WR. Corey S (1986) Distributional patterns of the ctenophores Pleurobrachia pileus and Beroe cucumis in the Bay of Fundy region, Canada. Can J Zool 64:2639-2644

Motoda S (1959) Devices of simple plankton apparatus. Mem Fac Fish Hokkaido Univ 7:73-94

Mountford K (1980) Occurence and predation by Mnemiopsis leidyi in Barnegat Bay. New Jersey. Estuar Coast Mar Sci 10:393-402

Nelson TC (1925) On the occurence and food habits of ctenophores in New Jersey inland coastal waters. Biol Bull Mar Biol Lab, Woods Hole 48:92-111

Purcell JE (1991) A review of cnidarians and ctenophores feeding on competitors in the plankton. Hydrobiologia $216 / 217: 335-342$

This article was submitted to the editor
Reeve MR, Walter MA (1978) Nutritional ecology of ctenophores - a review of recent research. Adv Mar Biol 15:249-287

Reeve MR, Walter MA, Ikeda T (1978) Laboratory studies of ingestion and food utilization in lobate and tentaculate ctenophores. Limnol Oceanogr 23:740-751

Schneider G (1987) Role of advection in the distribution and abundance of Pleurobrachia pileus in Kiel Bight. Mar Ecol Prog Ser 41:99-102

Siferd TD, Conover RJ (1992) An opening-closing plankton net for horizontal sampling under polar sea-ice. Sarsia 76 : $273-277$

Swanberg N, Båmstedt U (1991) Ctenophora in the Arctic: the abundance, distribution and predatory impact of the cyppidid ctenophore Mertensid ovum (Fabricius) in the Barents Sea. Pol Res 10:507-524

Swanberg N (1974) The feeding behavior of Beroe ovata. Mar Biol 24:69-76

UNESCO (1968) Zooplankton sampling. Imprimeries Populaires, Genève

van der Veer HW, Sadee CFM (1984) Seasonal occurence of the ctenophore Pleurobrachia pileus in the western Dutch Wadden Sea. Mar Biol 79:219-227

Wiebe PH, Morton AW, Bradley AM, Craddock JE, Barber V, Cowles TJ, Flierl GR (1985) New developments in the MOCNESS, an apparatus for sampling zooplankton and micronekton. Mar Biol 87:313-323

Williams R, Collins NR (1985) Chaetognaths and ctenophores in the holoplankton of the Bristol Channel. Mar Biol 85: $97-107$

Zelickman EA (1972) Distribution and ecology of the pelagic hydromedusae, siphonophores and ctenophores of the Barents Sea, based on perennial plankton collections. Mar Biol 17:256-264

Manuscript first received: May 30, 1995

Revised version accepted: November 3, 1995 